\title{
Reducing Financing Costs in Federal ESPCs
}

\author{
Patrick J. Hughes, Robert N. Baugh, John A. Shonder, \\ Erica Atkin, and Terry R. Sharp
}

December 2004

Prepared by

OAK RIDGE NATIONAL LABORATORY

P.O. Box 2008, Oak Ridge, Tennessee 37831-6285,

managed by UT-Battelle, LLC

for the

U.S. DEPARTMENT OF ENERGY under contract DE-AC05-000R22725 



\section{CONTENTS}

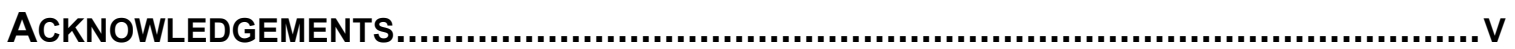

ABBREVIATIONS, INITIALISMS, AND ACRONYMS .................................................. VII

EXECUTIVE SUMMARY ..................................................................................

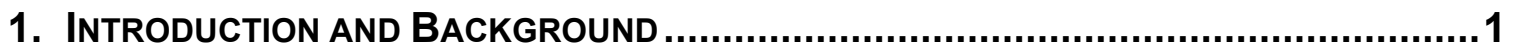

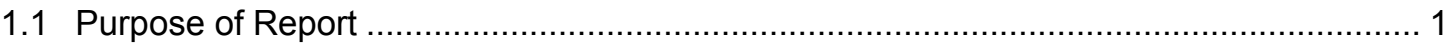

1.2 Working Group Fact-Finding and Recommendations .............................................. 1

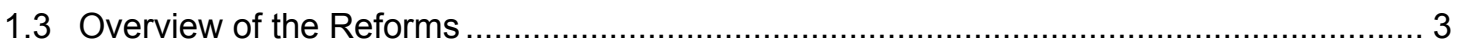

1.4 Benefits to Agencies, ESCOs, Financiers, and Investors …...................................... 5

\section{REQUIREMENTS FOR COMPETITIVE FINANCING ACQUISITION ..............................}

2.1 Use of Investor Deal Summary Is Required .................................................................... 7

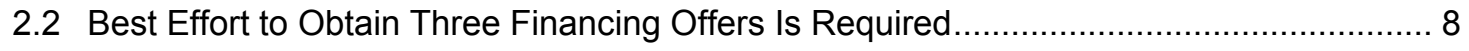

2.3 Investor Deal Summary — Required Content ........................................................... 8

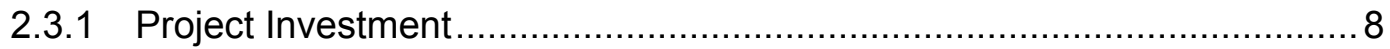

2.3.2 Key Project Dates ...................................................................... 9

2.3.3 Schedule of Payments That Will Reduce the Total Financed Amount .... 10

2.3.4 ESCO's Portion of Financing Procurement Price ................................ 11

2.3.5 Analysis of Risk of Interrupted Payments Due to Savings Shortfall ........11

2.3.6 Assessing Risk Associated With Guaranteed Savings......................... 11

2.3.7 The ESCO's Built-In "Safety Net" ................................................. 12

2.3.8 Government Payments for Performance-Period Services....................... 13

2.3.9 Mitigation of Risk by Payments for Performance-Period-Services .......... 13

2.3.10 Summary Risk Assessment.............................................................. 14

2.3.11 Specification of Financial Index ................................................... 14

2.3.12 Risk and Responsibility Matrix................................................. 14

2.3.13 Other Terms and Conditions ..................................................... 15

2.3.14 Other information........................................................................ 15

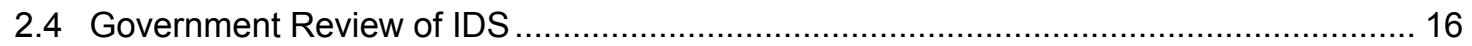

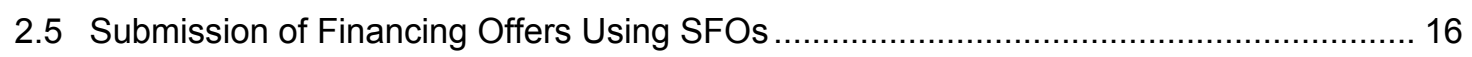

2.5.1 Standard Financing Offer - Required Content................................. 16

2.5 .2 Interpolated Index Interest Rates ................................................. 17

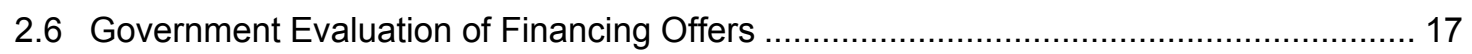

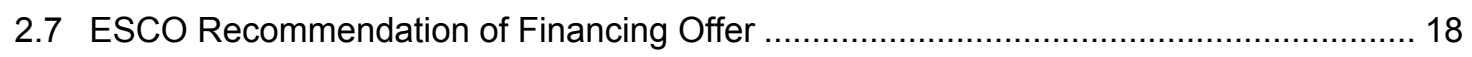

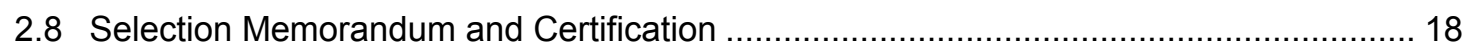

2.9 Final Proposal Based on Selected Financing Offer .................................................. 19 
APPENDIX A - SUPER ESPC IDIQ MOdIFICATIONS RELATED tO

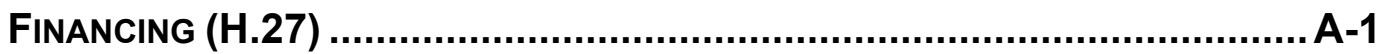

APPENDIX B - TEXT FOR SUPER ESPC RFPS TO IMPLEMENT

Recommendations of Financing Cost Reduction Working Group ..... B-1

ApPendix C — InVestor Deal Summary Template ....................................... C-1

APPENDIX D - EXAMPLES OF RISK ANALYSIS OF SUPER ESPC ECMs ................ D-1

ApPendix E — Standard Financing Offer Template .................................. E-1

ApPendix F - Calculating Index Rate Using Spline Interpolation

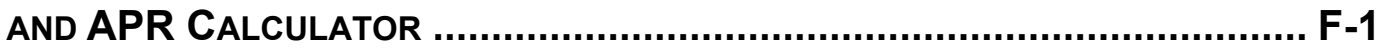




\section{ACKNOWLEDGEMENTS}

The members of the ESPC Financing Cost Reduction Working Group appointed by FEMP did the fact-finding, consultation, and analysis necessary to formulate the recommendations of actions FEMP and agencies could take in the short term that are described in this report and embodied in Section H.27 of the modifications to the Super ESPCs adopted in late 2004. The working group was chaired by Schuyler Schell, Acting Director of the Department of Energy's (DOE's) Federal Energy Management Program (FEMP); and the technical lead was Patrick Hughes, Oak Ridge National Laboratory. Working group members included Tatiana Strajnic, FEMP Alternative Financing Program Lead; Joyce Ziesler, Contracting Officer for the Super ESPC Program, DOE Golden Field Office; Douglas Dahle and Jeffrey Dominick, National Renewable Energy Laboratory; and Linda Mesaros, Mesaros Consulting Inc.

The working group relied heavily on the guidance received from both the Office of Management and Budget (OMB) and the U.S. Department of Treasury's Federal Financing Bank (FFB). Periodic meetings were held with OMB and FFB, both jointly and separately, to review the working group's interim findings and seek advice on next steps. Participants from OMB included Mark Weatherly, Deputy Associate Director of Natural Resource Programs; Rick Mertens, Chief of the Energy Division; Cynthia Vallina, Procurement Analyst for the Energy Division; and Rob Sandoli, Budget Examiner for DOE's Energy Efficiency and Renewable Energy Programs. Participants from FFB included Brian Jackson, Chief Financial Officer; Gary Burner, Manager; Whitney Culbretson, Financing Specialist; Peter Bieger, General Council; and Cynthia Reese, General Council.

The working group and the authors are indebted to many expert professionals in the fields of financing and energy savings performance contracting for generously sharing their time and knowledge to assist the working group with fact-finding, and for reviewing the draft contract modifications. They made these improvements possible.

Thanks to the professionals of the Super ESPC energy services companies for their helpful reviews and commitment to improving federal ESPC programs.

Thanks to finance professionals Jeffrey Eckel, John Christmas, and Nate Rose, HannonArmstrong; Bruce Gross, GE Capital; Anita Molino and Peter Flynn, Bostonia Partners LLC; Steve Allenby, United Financial of Illinois, Inc.; Patrick Keogh, AMV, LLC; David Miller, Shaw Pittman; Paul Penney, CTL Capital; Daniel Will, Credit Lyonnais Securities (USA) Inc.; John Johnson, Government Securities Research Ltd; and Richard L. Eppley, Hayes \& Co. 


\section{ABbreViations, INITIALISMS, AND ACRONYMS}

\begin{tabular}{ll} 
APR & Annualized percentage rate \\
CO & Contracting officer \\
COR & Contracting officer's representative \\
DES & Detailed energy survey \\
DO & Delivery order \\
DOE & U.S. Department of Energy \\
ECM & Energy conservation measure \\
ESCO & Energy services company \\
ESPC & Energy savings performance contract \\
FEMP & DOE Federal Energy Management Program \\
IDIQ & Indefinite-delivery, indefinite-quantity (contract) \\
IDS & Investor's deal summary \\
M\&V & Measurement and verification \\
NTP & Standard financing offer \\
O\&M & Notice to proceed with construction \\
P4 & Operations and maintenance \\
UFO & Pre-performance-period payment \\
UESC & Stily energy services contract \\
\hline
\end{tabular}




\section{EXECUTIVE SUMMARY}

This report documents the recommendations of a working group commissioned by the Federal Energy Management Program (FEMP) in 2002 to identify ways to reduce financing costs in federal energy savings performance contract (ESPC) projects. The working group is part of continuing efforts launched by FEMP since the award of the Department of Energy's (DOE's) Super ESPCs in 1998 and 1999 to ensure that practical, flexible, and cost-effective alternative financing for energy-efficiency improvements is available to all federal agencies.

During FY 2002 - 2004, the working group pursued extensive fact finding, consulted with government and private-sector finance experts, and analyzed data from federal and local government ESPC programs. The working group observed that both competition and transparency were lacking in federal ESPCs. The working group also found that the government often falls short of full compliance with certain provisions of the final rule that codifies the federal ESPC authority into regulation (10 CFR 436), which speak to due diligence in determining fair and reasonable pricing.

Based on these findings, the working group formulated their short-term recommendations of actions that agencies can take immediately to reduce ESPC financing costs. The working group recommended requiring competitive solicitation of offers from prospective financiers of ESPC projects, standardization of processes to keep the playing field level and reduce energy service companies' (ESCOs') project development costs, and assuring transparency by specifying that the government will see and review all bids. The reforms are intended to enable the government to determine quickly and reliably whether the portion of price related to financing is fair and reasonable and to provide auditable records of the transaction.

The working group's recommendations were incorporated into modifications to the Super ESPCs and requirements to be included in the Super ESPC delivery order request for proposal (DO RFP), which is used to tailor delivery orders to the particular needs of the ordering agency and becomes a part of the contract. The financing reforms are summarized below.

\section{Three financing offers}

The ESCO is required to solicit financing offers from a minimum of three financiers. The ESCO may itself be included among the three prospective financiers.

\section{Investor Deal Summary (IDS) required}

Financing will be solicited using an IDS prepared by the ESCO, based on the template provided by the government. Offers of financing must respond to the data and requirements given in the IDS. The IDS will expedite the process by providing a format for the ESCO to use and providing prospective financiers with all the information they need prepare an offer.

\section{Standard Financing Offer (SFO)}

Financiers will submit their offers to the ESCO in the form of a Standard Financing Offer, based on the SFO template provided by the government. Additional data that may be unique or specific to the project may also be included. 


\section{ESCO submits SFOs to government}

ESCOs will submit all SFOs received from financiers to the government and request and request a government evaluation of the offers.

\section{Government evaluates SFOs}

The government will evaluate the annualized percentage rate (APR) of all offers and provide this information to the ESCO.

\section{ESCO selects one offer}

The ESCO selects one financing offer for the project based on minimum APR or other criteria and prepares the final proposal accordingly.

\section{ESCO prepares selection memorandum}

The ESCO prepares a memo describing the competition and why the selected offer is the best value for the project, and certifies that the memo's contents are true, correct, and in accord with best business practices.

\section{Government's communications with financiers include ESCO}

Any communications with financiers desired by the government will be conducted jointly by the ESCO and government with the financier, unless the ESCO waives participation.

These reforms directly address concerns related to cost-effectiveness of ESPCs that were raised by several government audits and assessments of federal ESPCs awarded under DOE's and other agencies' programs. Incorporating these practices will mitigate many of the problems pointed out in those documents, but will also improve and strengthen federal ESPC programs to the benefit of all participants. With lower financing costs, ESPCs can have shorter terms, or agencies can gain more improvements for the same amount of money. Larger projects will add to the sales of private-sector ESCOs. The new requirements will also allow greater participation by more private-sector financiers. All participants will benefit from improvements that bolster confidence in the value of federal ESPCs and strengthen the case for permanent extension of the federal ESPC authority.

The IDIQ modifications related to financing were carefully crafted to ensure that they will neither delay the ESPC project development process nor burden ESCOs, financiers, or agencies with unreasonably costly or time-consuming procedures. Standardized forms are provided that define the minimum required information for ESCOs' use in soliciting financing offers and for financiers to include in their offers. Rather than slowing down negotiation and award of ESPCs, these standardized forms and procedures are expected to expedite solicitation, evaluation, and selection of financing offers. 


\section{Reducing Financing Costs for Federal ESPCs}

\section{INTRODUCTION AND BACKGROUND}

\subsection{Purpose of Report}

This report documents the findings of a working group commissioned by the Federal Energy Management Program (FEMP) in 2002 to identify ways to reduce financing costs in federal energy savings performance contract (ESPC) projects. The working group is part of continuing efforts launched by FEMP since the award of the Department of Energy's (DOE's) Super ESPCs in 1998 and 1999 to ensure that practical, flexible, and cost-effective alternative financing for energy-efficiency improvements is available to all federal agencies.

During FY 2002 - 2004, the working group pursued extensive fact finding, consulted with government and private-sector finance experts, and analyzed data from federal and local government ESPC programs. The working group's efforts culminated in financing-related modifications to the DOE Super ESPCs that focus on competition among prospective financiers of ESPC projects, standardization of processes to keep the playing field level and reduce energy service companies' (ESCOs') project development costs, and transparency of financing costs to the government.

This report details the financing-related modifications to the Super ESPCs and the new standardized processes of procuring financing for Super ESPCs. The following chapters and appendixes explain new requirements and roles of the ESCO, financier, and government, and provide guidance for all participants.

Although the reforms discussed here are being formally applied to DOE's Super ESPCs, these concepts can also be applied to other indefinite-delivery, indefinite-quantity (IDIQ) ESPCs and site-specific contracts. Agencies can immediately take the actions described here to reduce financing costs in their ESPCs.

These reforms directly address concerns related to cost-effectiveness of ESPCs that were raised by several government audits and assessments of federal ESPCs awarded under DOE's and other agencies' programs. Incorporating these practices will mitigate many of the problems pointed out in those documents, but will also improve and strengthen federal ESPC programs to the benefit of all participants. With lower financing costs, ESPCs can have shorter terms, or agencies can gain more improvements for the same amount of money. Larger projects will mean larger sales for private-sector ESCOs who provide them. The new requirements will also allow greater participation by more private-sector financiers. All participants will benefit from improvements that bolster confidence in the value of federal ESPCs and strengthen the case for permanent extension of the federal ESPC authority.

\subsection{Working Group Fact-Finding and Recommendations}

FEMP's financing-cost-reduction working group cast a wide net in exploring the opportunities for reducing ESPC financing costs. The working group analyzed data on financing costs in past federal, state, and local government ESPC projects and consulted with the financiers of the majority of federal ESPCs. Networking and data gathering extended to ESCOs, utilities, other federal alternative financing programs, state and local ESPC programs, Wall Street professionals, institutional investors, and the Department of the Treasury. 
The working group found that financiers are rarely given the opportunity to compete for ESPCs, but such competition is more common in utility energy services contracts (UESCs). It is common for ESCOs who develop ESPC projects to establish a relationship with one financier and call on that firm repeatedly. The working group also observed that transparency to the government of third-party financing offers is lacking, in some cases making it impossible even to verify whether the ESCO has offered the government the same terms the financier offered to the ESCO.

Their observations that both competition and transparency were lacking led the working group to conclude that financing costs for federal ESPCs could be reduced by requiring ESCOs to solicit three competitive financing offers from the commercial market and select the best one, and by ensuring that the financing transaction would be transparent to the government.

The working group anticipated objections from some ESCOs and financiers, who say they have relied on established, exclusive working relationships with each other to conserve corporate and government resources, because understanding and pricing the risk of financing ESPCs requires far more time than doing so for other investments of similar size. To ensure that competition would not require undue effort or cause delays in the process of awarding ESPCs, the working group proposed another requirement: that each prospective financier would be provided with a brief "investor deal summary" of project data and government requirements that would quickly convey all the project-specific information needed for rating the risk and composing an offer. The reforms assume that financiers would continue to assess ESCO credit, also essential for composing an offer, as they have in the past.

The working group also found that the government often falls short of full compliance with certain provisions of the final rule that codifies the federal ESPC authority into regulation (10 CFR 436). Although the final rule states that "...heads of procuring activities shall waive the requirement for submission of certified cost and pricing data" for federal ESPCs, the rule makes clear that this waiver:

“... is not intended to preclude COs [contracting officers] requesting information considered necessary to determine whether a contractor's prices are fair and reasonable." (10 CFR 436, Section D)

and

“... does not exempt offerors from submitting information (including pricing information) required by the Federal agency to ensure the impartial and comprehensive evaluation of proposals." [436.33(c)(2)]

The final rule specifies two requirements in particular to ensure that the financing agreements in ESPCs are in the government's best interest:

The government "...shall request the text of any third-party financing agreement." [436.33(a)(2)(i)]

ESPCs shall contain clauses "...requiring prior approval by the contracting officer of any financing agreements.” [436.35(a)(3), Mandatory Requirements]

Based on these findings, the working group moved from fact-finding to implementation in April 2004. The working group's short-term recommendations, addressing only the actions that agencies can take immediately to reduce financing costs, were developed in the form of draft modifications to the DOE Super ESPC IDIQ contracts. The focus of these reforms is simply to enable federal ESPC customers and their private-sector partners to continue awarding and 
implementing ESPCs, but in a way that complies with the final rule and reduces financing costs. The reforms focus on transparency, standardization, and competition in financing.

The first draft of the IDIQ modifications was presented and discussed at an internal FEMP meeting in late April 2004. The second draft was distributed in mid-June to ESCOs and to the Federal ESPC Steering Committee (comprising agency customers of ESPC), and was discussed at a half-day workshop with ESCOs and agencies in late June. The third draft was distributed to the ESCOs in late July 2004, and was the subject of a half-day meeting with the ESCOs in midAugust.

The proposed financing-related IDIQ modifications evolved significantly as a result of the vetting process with the ESCOs and agencies, and it became evident during this process that vetting with the financial community would also be worthwhile. In late August the fourth draft was distributed to firms currently financing federal ESPC projects and to others expressing an interest in either the financier or investor role. In early September all review comments were received, and in late September the fifth version of the modifications, having evolved further as a result of input from the financial community, was submitted for DOE legal and procurement review.

The final version of the IDIQ modifications includes some of the provisions recommended by the working group, but others are more appropriately implemented through their inclusion in the delivery order RFP, which is used to tailor the Super ESPC IDIQ to the particular needs of the ordering agency. The final IDIQ modifications related to financing and language for the RFP to implement the working group's recommendations are given in Appendixes A and B, respectively.

\subsection{Overview of the Reforms}

The financing reforms recommended by the working group are summarized below. All of these reforms are embodied in the modified section H.27 of the contract, given in Appendix A of this document, or in language to be included in the delivery order RFP, given in Appendix B. These requirements are discussed in more detail in the following sections of this report.

The modifications to the DOE Super ESPC IDIQs are intended to enable the government to determine quickly and reliably whether the portion of price related to financing is fair and reasonable and to provide auditable records of the transaction. The modified contract provisions require competitive solicitation of financing for ESPCs and increase the transparency of the financing process by giving the government the authority to interact with the ESCO and prospective financiers to ask questions or seek clarifications regarding their offers.

\section{ESCO required to solicit three financing offers}

The ESCO is required to solicit financing offers from a minimum of three financiers. The ESCO may itself be included among the three prospective financiers.

\section{Use of Investor Deal Summary (IDS) required}

Financing will be solicited using an Investor Deal Summary (IDS) prepared by the ESCO. The IDS will be based on and contain the information specified in the template provided by the government. Offers of financing must respond to the data and requirements given in the IDS. The IDS will expedite the process by providing a format for the ESCO to use and providing prospective financiers with all the information they need (in addition to ESCO credit standing, which they assess themselves) to rate and quote the terms of an offer quickly, without having to search for key data. 


\section{Offers must be in the form of a Standard Financing Offer (SFO)}

Financiers will submit their offers to the ESCO in the form of a Standard Financing Offer (SFO), based on the SFO template provided by the government. Additional data that may be unique or specific to the project may also be included. Offers are to be submitted on the financier's letterhead by the due date specified in the IDS.

\section{ESCO submits SFOs to government}

ESCOs will submit all SFOs received from financiers (including the ESCO's SFO if internal ESCO funding is being considered) to the government. The ESCO will request a government evaluation period of not less than one week.

\section{Government evaluates SFOs}

All offers will be evaluated by the government. The government will calculate the annualized percentage rate (APR) of all SFOs using its own methodology and provide this information to the ESCO. If the ESCO's best efforts resulted in only one SFO, the government will evaluate whether its APR is in the program-wide competitive range. The government will provide the evaluation results to the ESCO.

\section{ESCO recommends selection of one offer}

The ESCO recommends one financing offer for the project and prepares the final proposal accordingly. Selection may be based on minimum APR, but other selections may be recommended using project-specific justifications. The ESCO and government will generally agree on selection, but if agreement is not possible, the ESCO makes the selection. The ESCO completes the final proposal based on the financing offer selected.

\section{Government verifies the offer in the ESCO's final proposal}

The government verifies that the financing offered by the ESCO in the final proposal is consistent with the selected financier's offer to the ESCO. During final negotiations the government considers all aspects of the ESCO's final proposal offer and issues an award if an acceptable project can be negotiated.

\section{Government's communications with financiers include ESCO}

Any communications with financiers desired by the government (for clarifications, explanation of terms and conditions, etc.) will be conducted jointly by the ESCO and government with the financier, unless the ESCO waives participation.

\section{Selection memorandum}

The ESCO prepares a memo describing the competition, number of offers solicited and received, rationale for selecting the financier, and why the selection is the best value for the project. A representative of the ESCO who is authorized to obligate funds is required to certify to the government that the contents of the selection memorandum are true, correct, and in accord with best business practices.

\section{Documentation}

The ESCO will submit the IDS, SFO, selection memorandum, and certification with the price proposal in the final proposal. 


\subsection{Benefits to Agencies, ESCOs, Financiers, and Investors}

Requiring competition and assuring transparency in the financing of federal ESPCs through instituting the reforms recommended by FEMP's working group will benefit agencies, ESCOs, financiers, and investors. The reforms directly address concerns that were raised by several government audits and assessments of federal ESPCs awarded under DOE's and other agencies' programs. Adopting these practices will mitigate many of the identified problems, as well as bolstering confidence in the value of federal ESPCs and strengthening the case for permanent extension of the federal ESPC authority.

The new requirements for competition will reduce financing costs in Super ESPCs by allowing natural market forces to take their course. More financiers will have the opportunity to bid on and finance federal ESPCs, and through them, more investors will be drawn to federal ESPCs as an investment opportunity. As more investors are included and educated, they will increasingly regard federal ESPCs as high-value investments, creating another level of competition that could further reduce financing costs. Also, as financiers cultivate relationships with more ESCOs, they may find opportunities for aggregation of ESPC investments that would be attractive to larger and more competitive investors.

The standardized procedures and documents will give prospective financiers (as well as investors, ESCOs, and agencies) a better, more realistic understanding of the risk factors in financing federal ESPCs. When Super ESPC projects are fully understood, risk to the investor is often revealed to be modest, and effective communication of this information will allow financiers to offer interest rates that reflect the minimal risk.

The standardized processes and forms are designed to make efficient, economical use of all parties' resources. The use of the IDS and SFO forms will ensure that all parties are-literallyon the same page, and will quickly communicate the information needed to expedite the process.

The IDS establishes a common basis for competition by specifying the ESCO's and government's preferences and acceptable terms and conditions for financing offers for the project. The SFO will put all financing offers in a form that is easily understood by all parties and will facilitate timely review by the government. A considerable factor in financing cost has been, according to financiers and ESCOs, the difficulty and complexity of rating the risk of ESPC investments because they are not a standard financing commodity. Financiers and investors have commonly had to sort through the entire volume of ESPC award documents to find the information that will now be presented on a few pages in the IDS.

The new process will also engender better congruence between the agency's and ESCO's goals, because both parties will be motivated to achieve award of the delivery order within the time period during which the financier is committed to hold firm the quoted premium over index and up-front financing costs.

The transparency of financing procurements is required to demonstrate due diligence in determining that the pricing of ESPC financing is fair and reasonable. The reforms give agencies the right to see all bids and the authority to communicate directly with financiers (with ESCO participation) to ask questions and seek clarifications. Transparency will reassure the government that ESPC financing costs are reasonable, thereby encouraging more agencies to participate in federal ESPC programs, and will also strengthen the case for permanent extension of the ESPC authority.

These reforms institutionalize better support to agencies using ESPCs by requiring government evaluation of all financing offers. Audits and assessments of federal ESPC programs have strongly recommended that better support be provided, and agencies clearly lack financing 
expertise and have actively sought such support. The government's evaluation of SFOs will provide the technical support needed to ensure that agencies understand their options, that all cost-saving strategies are considered on all projects, and that ESPC final proposals will reflect best value to the government.

Government evaluation of SFOs could also contribute to reducing costs by providing data on federal ESPCs to inform the financial markets. Risks are rated largely in relation to uncertainty, and costs can be reduced when financiers can be given accurate information on the history of risk factors such as ESCO defaults or the government's withholding of payments.

ESCOs and agencies will benefit most directly from these reforms. With reduced financing costs, agencies can use more of the project cost savings to either shorten the contract term (and further reduce costs), or to get a more comprehensive project with more improvements. And with lower financing costs, ESCOs will benefit from increased sales. 


\section{RequiRements For Competitive FinanCing ACQUisition}

The new requirements for competition and transparency in financing for federal ESPCs were designed to achieve best value for the government and satisfy government standards of due diligence in determining fair and reasonable pricing of government-procured goods and services. In complying with the new requirements, agencies will compile documentation that can definitively demonstrate their due diligence to auditors and program evaluators.

The IDIQ modifications related to financing were carefully crafted to ensure that they will neither delay the ESPC project development process nor burden ESCOs, financiers, or agencies with unreasonably costly or time-consuming procedures. Standardized forms are provided that define the minimum required information for ESCOs to use in soliciting financing offers and for financiers to include in their offers. Rather than slowing down negotiation and award of ESPCs, these standardized forms and procedures are expected to expedite solicitation, evaluation, and selection of financing offers.

\subsection{Use of Investor Deal Summary Is Required}

The ESCO is required to solicit three financing offers from the commercial market using a competitive process. If willing and able to provide financing from within its own organization, the ESCO may submit one of the three offers itself. The solicitations for any single project will contain identical materials to establish a common basis for competition. Each solicitation will include the following:

- Investor Deal Summary (IDS) - prepared by the ESCO using the template provided by the government

- Completed Risk/Responsibility Matrix — already a required part of the final proposal

- A deadline for ESCO receipt of offers

The IDS is essentially a request for a financing offer - a concise statement of the ESCO's and government's requirements, key dates, financial data, and risk analysis for the project. An IDS template provided by the government (described in detail in Section 2.3 and shown in Appendix C) specifies the required information. Additional data may be added at the ESCO's discretion.

Use of the IDS will standardize the process of soliciting and negotiating the financing deal and minimize the time and effort required for both ESCOs and financiers to participate. The IDS will establish clear parameters for competition and provide all the information about the project the financier needs to develop an offer. The ESCO will prepare the IDS after completing the detailed energy survey (DES) and reaching agreement with the agency on the scope of the project. At that point all the information needed for the IDS should be available, and completing it should take about one business day.

The ESCO will send the completed IDS to the agency contracting officer (CO), DOE CO, and DOE contracting officer's representative (COR) electronically, in Microsoft Word format, for review before sending it to prospective financiers to solicit their offers. The government is advised to review the IDS to ensure that it is accurate and complete. The ESCO will also send record copies of the final IDS to the agency, DOE CO, and DOE COR. 


\subsection{Best Effort to Obtain Three Financing Offers Is Required}

Concerns have been expressed related to the cost, effort, or even possibility of obtaining three financing offers, and these concerns are understood. We expect, however, that transparency and competition will result in reductions in the financier's portion of the financing procurement price that will compensate for any increase in the ESCO's effort (and cost) to arrange financing, which is also a component of financing procurement price.

Our consultations with several successful ESCOs indicate that establishing new financing relationships involves a modest one-time effort over a period of a few weeks. We expect that the new forms and procedures will quickly become routine and in the long run will show definitive cost savings in required effort.

We recognize that the ESCO's credit standing may limit the participation of some financiers. If the ESCO makes its best effort to secure offers from three financiers but fails, the government can accept fewer financial offers, and can accept the ESCO's financing, if competitive with procurement history. The ESCO would be expected to provide justification and documentation of the process.

Verifying the competitiveness of the ESCO's financing offer without other offers for comparison would be more difficult. Although the government can compare a single offer to past project financing on the basis of APR, direct comparison of two or three offers for the project would provide more conclusive data to auditors.

Small project size can also limit financiers' interest, but the program-wide standardization, transparency, and competitive process engender improved opportunities for financiers to aggregate several projects to achieve proportions more attractive to investors.

\subsection{Investor Deal Summary - Required Content}

The sections of the IDS template (1 through 12) are shown below, with a discussion of required content. The template should be modified as necessary to accommodate the individual project.

\subsubsection{Project Investment}

\begin{tabular}{|l|c|l|l|c|}
\hline \multicolumn{1}{|c|}{ 1. Project Investment } \\
\hline ECM description & $\begin{array}{c}\text { Implementation } \\
\text { expense (\$) }\end{array}$ & Markup (\%) & $\begin{array}{c}\text { Implementation } \\
\text { price (\$) }\end{array}$ & $\begin{array}{c}\text { Percentage of } \\
\text { implementation } \\
\text { price (\%) }\end{array}$ \\
\hline & & & & \\
\hline & & & & \\
\hline & & & & 100 \\
\hline Totals & & & & \\
\hline
\end{tabular}

The first section of the IDS shows implementation price for each energy conservation measure (ECM). Implementation price includes implementation expense (design and construction costs) plus the ESCO's markup. The IDS can be prepared only after the DES has been completed and the price quotations for design and construction have been obtained. Implementation prices are 
contained in Super ESPC Schedule DO-2. The total financed amount equals total implementation price plus financing procurement price minus any payments listed in section 3 of the IDS.

\subsubsection{Key Project Dates}

This section gives target dates upon which financiers will build their offers.

The financing provider will be selected in advance of delivery order award and financial closing. Prospective financiers are asked to provide quotes on the premium component of the interest rate and the financier's portion of the financing procurement price and to hold those quotes firm until a specified date that would allow time for the ESCO and agency to finalize negotiation and award of the

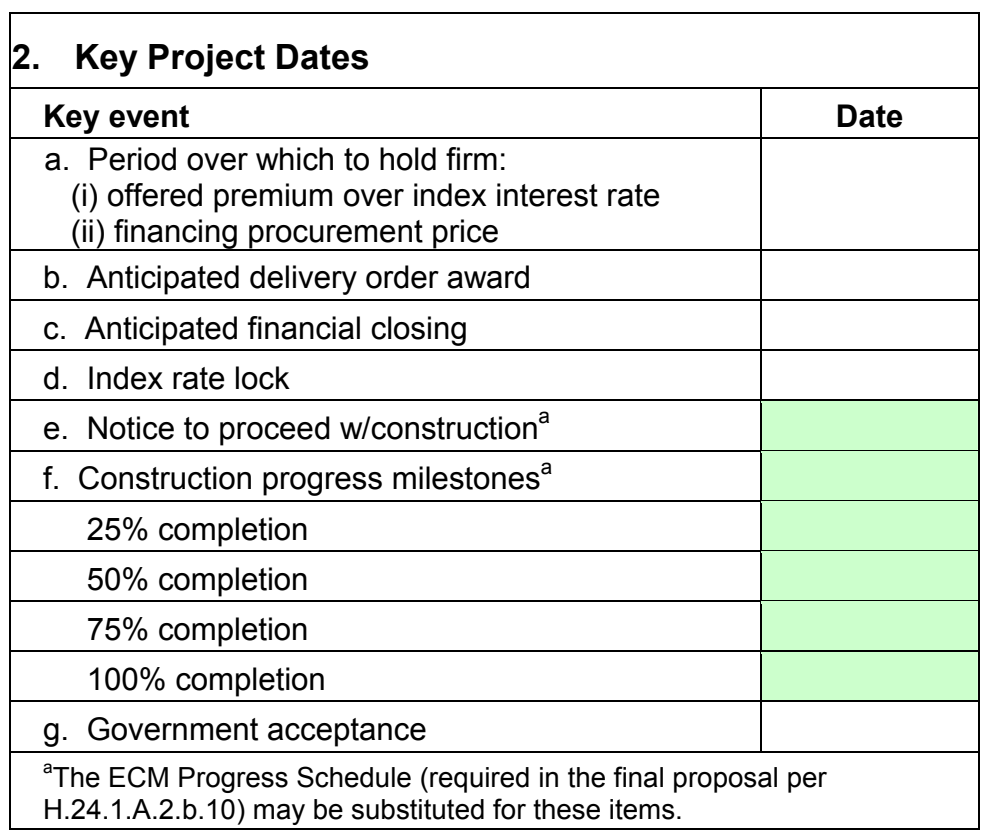
delivery order.

Since in most cases neither

ESCOs nor financiers have a cost-effective way to hedge the risk of changes in the index component of the project interest rate between when the financing offer is selected and the date of closing on the permanent financing, agencies are advised to let the index portion of the interest rate float until financial closing. Closing on the permanent financing, award of the delivery order, and lock of the index rate may, but do not always, occur on the same date. The index interest rate can be locked a day or two before or after award without requiring any sort of hedge fee.

Depending on the volatility of index interest rates, an agency may prefer to have the ESCO or financier purchase a hedge to lock the index rate when the financing offer is accepted instead of at financial closing (i.e., award) and include the cost of the hedge in the financing procurement price.

Whether the index interest rate is held firm or allowed to float until closing, the ESCO and agency will be motivated to work together to achieve award by the target date so that the financing deal will hold. If a hedge is used to lock the index rate, the consequences of not achieving award by the target date are more severe if the index rate has risen by that time, because the expense of the hedge product will have been wasted, and the project as structured may not pay from savings given a higher index rate and more expensive financing.

Generally the permanent financing closing occurs at the time of delivery order award. If so, proceeds of the financing are generally assigned to a fiduciary, who invests the funds conservatively while they are held in escrow. The fiduciary ensures that the government has issued the notice to proceed with construction (NTP) and that specified construction milestones are met before the ESCO may draw the corresponding progress payments to cover design and 
construction from the financing. Until then, the ESCO uses its own working capital to develop the project and fund design activities.

After NTP, progress payments from the financing can be drawn to replenish the ESCO's working capital and pay for the design, equipment, and construction subcontractors necessary to implement the project. During the implementation period (between award and acceptance-also called the construction period) the fiduciary pays the interest that accrues on the financing. Since interest paid to the investor exceeds interest earned on the funds held in escrow, funds assigned to the fiduciary at closing must be sufficient to cover the difference (called capitalized constructionperiod interest) as well as ESCO progress payments. After agency acceptance of the operating project, the ESCO draws the final payment from the financing, and the agency begins making debt-service payments of principal and interest, plus the amount due for performance-period services provided by the ESCO.

The foregoing describes the most common form of federal ESPC financing. ESPC financing may alternatively be structured as two loans. Options for the second funding source include a shortterm construction loan taken at the time of delivery order award and drawn upon as milestones are completed, or use of ESCO working capital in lieu of a construction loan. In the two-loan scenario, the permanent financing closes after project acceptance and is applied to retire the construction loan or replenish ESCO's working capital. Financiers can model the financing in both ways to determine which is to the government's advantage. Whether structured as two loans or one, interest accrues during the construction period and the amount of construction-period interest is capitalized as part of the financing procurement price.

Taking the permanent financing at award, instead of at project acceptance, is most common because it avoids a costly hedge product to cover index rate risk between award and a later permanent financing closing date. Although capitalized construction-period interest is higher if the permanent financing is taken at award, the incremental cost is generally less than the hedge cost would be.

The financing reforms accommodate any of these options, and the structuring of the financing will affect the financier's quotes on the premium component of the interest rate and the financier's portion of the financing procurement price.

\subsubsection{Schedule of Payments That Will Reduce the Total Financed Amount}

Payments that will reduce the financed amount are to be specified in section 3 of the IDS. Such payments could include utility rebates and other energy-conservation incentives and preperformance-period payments $(\mathrm{P} 4 \mathrm{~s})$.

\section{Payment to Reduce Total Financed Amount}

\begin{tabular}{|l|l|l|}
\hline Type of payment & Amount (\$) & Anticipated date \\
\hline a. Pre-performance-period payment & & \\
\hline b. Utility rebate & & \\
\hline $\begin{array}{l}\text { c. Other ECM financial incentive (i.e. state } \\
\text { system benefit fund) }\end{array}$ & & \\
\hline
\end{tabular}

P4s are remitted by the government to the ESCO after award of the contract and before or at acceptance of the ESPC project - early enough in the process to reduce the amount financed by displacing progress payments. These payments are shown in "Year 0" on Schedule DO-1. Like all 
other ESPC payments, P4s must come from savings. Savings generated during the construction period are commonly paid to the ESCO as a P4. A variety of one-time savings from expenses avoided because of the ESPC can also be applied as P4s. (For more information on one-time savings, see the Practical Guide to Savings and Payments, Sections 3.6, 4.4 and 5.5, available at www.eere.energy.gov/femp/financing/superespcs_espcbasics.cfm.)

\subsubsection{ESCO's Portion of Financing Procurement Price}

Section 4 shows the ESCO's portion of the financing procurement price. This includes the ESCO's effort and expenses associated with procuring financing, such as the cost of payment and performance bonds, cost of effort, and other closing costs and fees. The financier's portion of financing procurement price should not be included in this amount.

\begin{tabular}{|l|l|}
\hline 4. ESCO's Portion of Financing Procurement Price & Amount (\$) \\
\hline $\begin{array}{l}\text { ESCO's portion of financing procurement price, (e.g., payment and } \\
\text { performance bonds, contractor costs for arranging financing, etc.) }\end{array}$ & \\
\hline
\end{tabular}

\subsubsection{Analysis of Risk of Interrupted Payments Due to Savings Shortfall}

Sections 5 through 9 of the IDS summarize data that describe a risk of primary concern to the financier and investor - the risk that debt-service payments will be interrupted. In federal ESPCs, the government may reserve the right to withhold payments if verified savings fall short of the guarantee. Some financiers have perceived this risk to be great enough to warrant relatively high premiums. This analysis will reveal what the actual risk of payment interruption is, which, depending on the project, may be modest or even negligible. Ensuring that this information is communicated clearly will enable prospective financiers to base their offers on a realistic assessment of their risk.

The risk of debt-service payments being interrupted because of savings shortfalls is mitigated by a "safety net" built into most federal ESPCs, which is calculated in section 6 of the IDS. Another mitigating fact is that in most ESPCs a large percentage of the guaranteed savings are not at risk at all or have a low risk, because of the terms of the negotiated contractual agreement, including the M\&V plan. IDS sections 5, 6, and 8 show the proportions of project savings in at-risk, lowrisk, and no-risk categories. The financier should also be aware that ESCO services to the agency during the performance period are part of most ESPCs, and the government's payments for those services constitute significant protection of the government's debt-service payments. Data characterizing this aspect of the project is shown in IDS sections 7, 8, and 9.

\subsubsection{Assessing Risk Associated With Guaranteed Savings}

Showing where savings are coming from is the first step in assessing the risk that achievement of guarantee savings could be disputed and cause the government to withhold debt service payments. The risk is based primarily on the type of $M \& V$ required to verify savings rather than on the type of ECM. Three categories characterize the degree of this risk:

- No risk - Savings in energy-related operations and maintenance (O\&M) that are firm and stipulated, for example, when a maintenance contract can be discontinued because of the ESPC. 
- Low risk - Savings based on stipulated values such as, for a lighting retrofit, agreement that savings will be credited based on a set number of operating hours and $\mathrm{kW}$ savings per fixture, and periodic verification that fixtures are in place and functioning. Most savings subject to verification using M\&V Option A methods belong in this category.

- At risk - Savings subject to ongoing measurements, normally using M\&V Options $\mathrm{B}, \mathrm{C}$, or D.

Section 5 of the IDS summarizes the risk associated with the guaranteed project savings in the first three years of the performance period.

\begin{tabular}{|c|c|c|c|c|c|c|}
\hline \multirow[b]{2}{*}{ Guaranteed annual cost savings } & \multicolumn{2}{|c|}{ Year 1} & \multicolumn{2}{|c|}{ Year 2} & \multicolumn{2}{|c|}{ Year 3} \\
\hline & $\$$ & $\%$ & $\$$ & $\%$ & $\$$ & $\%$ \\
\hline \multicolumn{7}{|l|}{${ }^{a}$ At risk } \\
\hline \multicolumn{7}{|l|}{${ }^{b}$ Low risk } \\
\hline \multicolumn{7}{|l|}{${ }^{c}$ No risk } \\
\hline \multicolumn{7}{|l|}{ Total guaranteed savings } \\
\hline \multicolumn{7}{|c|}{$\begin{array}{l}{ }^{a} \text { Guaranteed savings "at risk" are subject to verification by ongoing measurements, such as M\&V Options } B, C \\
\text { and D. }\end{array}$} \\
\hline \multicolumn{7}{|c|}{$\begin{array}{l}\text { bow-risk guaranteed savings are subject to annual verification that ECM is in place and functioning, and } \\
\text { savings from ECMs verified by M\&V Option A. }\end{array}$} \\
\hline
\end{tabular}

More information on $\mathrm{M} \& \mathrm{~V}$ and Options $\mathrm{A}, \mathrm{B}, \mathrm{C}$, and $\mathrm{D}$ are available in the FEMP $M \& V$

Guidelines, in Detailed Guidelines for Use of $M \& V$ Option A, and in other resources on FEMP's web site at www.eere.energy.gov/femp/financing/superespcs mvresources.cfm.

Examples of risk assessments on a number of Super ESPC ECMs are given in Appendix D.

\subsubsection{The ESCO's Built-In "Safety Net"}

Section 6 of the IDS quantifies the "safety net" that most ESCOs build into their final proposals. The ESCO estimates project savings as accurately as possible, then in most cases guarantees less than $100 \%$ of the estimated savings. The difference between estimated and guaranteed savings represents a decreased risk of a savings shortfall.

\section{Comparison of estimated and guaranteed cost savings}

Amount by which annual estimated cost savings exceed guaranteed cost savings (Values for Year 0, no escalation applied)

\begin{tabular}{|l|l|l|}
\hline \multicolumn{1}{|c|}{ Total project } & $\$$ & $\%$ \\
\hline Total estimated savings & & \\
\hline Total guaranteed savings & & \\
\hline Amount total estimated savings exceeds total guaranteed savings & & \\
\hline \multicolumn{1}{|c|}{ Savings in at-risk category } & & \\
\hline Estimated at-risk savings & & \\
\hline Guaranteed at-risk savings & & \\
\hline Amount estimated at-risk savings exceeds guaranteed at-risk savings & & \\
\hline
\end{tabular}




\subsubsection{Government Payments for Performance-Period Services}

Government payments to the ESCO for performance-period services assigned to the ESCO in the ESPC contract, such as M\&V, O\&M, repair and replacement, and training, are shown in section 7. These payments are separate and distinct from the implementation price and are not included in the financed amount. Performance-period payments are, however, included in the overall ESPC payment stream, can mitigate the financier's risk, and are a factor that should influence the pricing of the financing offer.

\section{Payments for Performance-Period Services}

\begin{tabular}{|l|l|l|l|}
\hline & Amount (\$) & $\begin{array}{c}\text { Anticipated start } \\
\text { date }\end{array}$ & $\begin{array}{c}\text { Frequency of payments } \\
\text { (monthly, quarterly, } \\
\text { annual) }\end{array}$ \\
\hline $\begin{array}{l}\text { Total performance-period services } \\
\text { payment }\end{array}$ & & & \\
\hline
\end{tabular}

\subsubsection{Mitigation of Risk by Payments for Performance-Period-Services}

Investors generally require first rights to the entire government payment stream to minimize the risk of defaults on debt service. The payments are generally assigned to a fiduciary who sends part of the payment to the ESCO for performance-period services, with the rest of the payment comprising debt service of interest and principal. In the event of a savings shortfall, the government could reduce payments to compensate. To prevent default on the debt service payments, the fiduciary could divert the performance-period-services portion of the government's payments to debt service. Through the assignment of claims, the investor's position is superior to the ESCO's, and debt service is protected as long as the reduction in the payment stream does not exceed the portion of the government's payments originally intended for the ESCO.

IDS section 8 compares at-risk guaranteed savings to performance-period-services payments that could be withheld by a fiduciary to cover debt service. This comparison gives the prospective financier a realistic perspective on the financial risk represented by a federal ESPC.

The percent shortfall in at-risk savings, and corresponding reduction in the payment stream, that could occur without affecting debt service is determined by dividing the performance-periodservices payment by the at-risk guaranteed cost savings value. For example, if the performanceperiod-services payment is $\$ 10,000$ and at-risk savings is $\$ 13,500$, there could be a $74 \%$ shortfall $(\$ 10,000$ divided by $\$ 13,500)$ in at-risk savings and corresponding reduction in government payments before the debt-service portion of government payments would be affected.

\section{Savings Shortfall Required Before Exceeding Payment for ESCO Performance-Period Services}

\begin{tabular}{|l|l|l|l|}
\hline & Year 1 & Year 2 & Year 3 \\
\hline At-risk guaranteed savings (\$) & & & \\
\hline Performance-period services payment (\$) & & & \\
\hline $\begin{array}{l}\text { Percent shortfall in at-risk savings before } \\
\text { performance-period-services payment is exceeded }\end{array}$ & & & \\
\hline
\end{tabular}




\subsubsection{Summary Risk Assessment}

IDS section 9 is to describe the events that would cause the government to withhold payments and the probability of their occurrence. Prospective financiers will need to know that although savings shortfalls have occurred in federal ESPCs, to our knowledge, the government has never withheld payments. In each case the government accepted the ESCO's remedy and the restoration of guaranteed savings. The government would not be expected to withhold payments unless there were a significant savings shortfall and the ESCO failed to fulfill its obligations to remedy the problem.

\section{Events Required to Trigger Government Withholding of Payments and Likelihood of Occurrence}

[Text - Brief narrative describing post-acceptance events required to trigger government withholding of payments and likelihood of occurrence of those events.]

\subsubsection{Specification of Financial Index}

All financing offers are to be based on the financial index specified in IDS section 10.

10. Applicable Financial Index (i.e. U.S. Treasury, Swap Rate, etc.)

\subsubsection{Risk and Responsibility Matrix}

\section{Risk Assignment Summary: Refer to Completed Risk and Responsibility Matrix}

[Attach completed Risk and Responsibility Matrix.]

Each party to an ESPC contract bears a share of the risk and responsibility. During ESPC project development, the government and the ESCO work through the issues considering the level of risk they are willing or able to assume, the responsibilities associated with the risk, and the consequences of failing to fulfill those responsibilities. Resolution of these issues is documented in the Risk and Responsibility Matrix, which addresses performance, operational, and financial risks and becomes part of the contract. 
The Risk and Responsibility Matrix is available on FEMP's web site at www.eere.energy.gov/femp/financing/superespcs_espcbasicsp2.cfm.

The financier may have an interest in which party is assigned certain risks and responsibilities if they are related to any potential for disputes to arise or for payments to be withheld. For example, the ESCO is always responsible for maintenance of ECMs in ESPC, but often the government's staff are used to perform the maintenance actions specified by the ESCO. If savings shortfalls occur in this case, the risk of government payments being withheld is reduced, because the maintenance logs may trace the problem to the government.

\subsubsection{Other Terms and Conditions}

\section{Applicable Financing Terms and Conditions (as required)}

In consultation with the government, the ESCO may use section 12 to specify terms and conditions that are not addressed elsewhere in the IDS. Agencies are expected to use their own judgment in considering provisions such as the following, or others.

- Make-whole - Detailing the government's liability in case of termination for convenience decreases the financier's uncertainty. This provision has been included in Super ESPCs and resulted in lower interest rates than obtained for other awards made during the same time period.

- No-offset - The working group that recommended the reforms described in this report does not recommend waiving the government's customary offset rights. However, some agencies have done so to gain more favorable interest rates on their ESPCs.

- Acceptance certificates - Financiers consider the unwillingness of government COs to issue acceptance certificates for completed ESPC projects to be a significant liability. Agencies could work with their organizations to ensure that these certificates would be issued.

\subsubsection{Other information}

The ESCO and agency may include additional information at their discretion, such as the following.

- Agency history - Financiers' experience of late ESPC payments, which represent a significant cost to them, are priced into premiums by many financiers. Providing a verifiable history of on-time payments to financiers could assure them that they will not bear the cost of late payments.

- ESCO financial strength - A major factor in evaluating the risk of financing an ESPC is the financial strength of the ESCO. We assume that financiers will evaluate the ESCO's financial standing according to their own established practices. However, we understand that many financiers would prefer to see three years of audited financial statements on the ESCO. 


\subsection{Government Review of IDS}

The ESCO will send the completed IDS electronically, in Microsoft Word format, along with an ESCO point of contact, to the agency CO, DOE CO, and DOE COR for review before sending it to prospective financiers to solicit their offers. The ESCO will request a government review and comment period of not less than one week. Government review is intended to verify that the IDS conveys accurate information and communicates the true, and generally modest, repayment risk investors face on these projects. The government will also provide information or guidance where needed for completion of the IDS, such as the amount and schedule of a P4. Government review of the IDS can be completed quickly and will prevent delays later in the process that would result from providing inaccurate information to prospective financiers.

\subsection{Submission of Financing Offers Using SFOs}

All financiers' offers must be submitted to the ESCO by the due date specified in the IDS, on the financier's letterhead, in electronic pdf format. The offers must be in the form of a Standard Financing Offer, based on the SFO template provided by the government. (See Appendix E.) Additional data that may be unique or specific to the project may also be included.

\subsubsection{Standard Financing Offer - Required Content}

A template for the SFO is provided to ensure that the offers contain all information required to conduct a proper evaluation of the offer, and to facilitate such an evaluation. The SFOs prepared by the prospective financiers should include the following minimum required content.

1. Narrative description of financing package that communicates a full understanding of the financing offer, addressing issues such as the following.

a. Third-party or internal financing of capitalized construction-period interest

b. Establishment of escrow or trust accounts for construction draws, performance-period administration, or other purposes

c. Timing of project financing closing and date certain for initiation of repayments (if applicable)

d. Timing of government payments, such as monthly, quarterly, annually in advance, monthly in arrears, etc.

2. Implementation price used in developing the offer (confirm that the value from IDS was used)

3. Itemized Financing Procurement Price. Itemize all up-front charges that flow to financing procurement price (which will be shown in Schedule DO-3 of the ESCO's final proposal), such as the following.

a. Itemized charges for any fees, professional services, etc., required by the financier to complete the transaction

b. Capitalized construction-period interest. State all interest rates that apply and any assumptions not specified in the IDS. Include hard copy and an Excel file showing the calculations used to determine capitalized construction-period interest. 
c. Hedge costs (only applicable if the IDS specifies that the index portion of total project interest rate is to be held firm until closing along with premium over index and financing procurement price)

d. ESCO's portion of the financing procurement price, provided by the ESCO in the IDS. (This covers the ESCO's price for arranging financing, pass-through of payment and performance bond costs, and any other applicable and documented costs.)

4. Pre-performance-period payments (P4s) (from the IDS)

5. Total amount financed (implementation price plus financing procurement price minus $\mathrm{P} 4 \mathrm{~s}$ )

6. Summary of the financing offer including:

a. The date to which all aspects of the offer are held firm (from the IDS)

b. Premium over index interest rate (annual); or, if government specified in the IDS that the index portion of the interest rate will be held firm until closing, then this should be the total annual interest rate, indicating values of both index and premium.

c. Financier's portion of financing procurement price.

d. Term of the loan (months), which is also the performance-period term.

e. An amortized schedule of government debt service payments, with calculations (submitted both as hard copy and electronic Excel file).

f. Backup for value of capitalized construction-period interest, electronically in Excel format, including all supporting calculations.

\subsubsection{Interpolated Index Interest Rates}

To ensure that all financing offers will be directly comparable and facilitate their evaluation, all financing offers will be based on the index specified by the government and the ESCO in the IDS. Financiers are to base their offers on an index maturity equal to the performance-period term (i.e., for a 17-year performance period use an index having a maturity of 17 years). If the performance period is not exactly equal to any maturity of a specific index, then it is recommended that a smoothed cubic spline fit be used to approximate the rate curve. This method allows the interpolation of interest rates for given maturities even when no paper was sold at those maturities. Appendix F presents more information on calculating a cubic spline fit.

\subsection{Government Evaluation of Financing Offers}

The ESCO will submit all received SFOs as electronic files in pdf format to the federal agency, DOE CO, and DOE COR, and request that the government complete its evaluation in not less than one week. The ESCO will provide points of contact for its own organization and for each financier that has submitted an offer.

The principal element of the government's evaluation is calculating the annualized percentage rate (APR) of each financing offer. APR is a percentage calculation that reflects the total cost of a loan (interest plus fees) on an annual basis. The APR calculated by the government on financing offers includes the base index interest rate, the premium over index, and the up-front financing procurement price. The APR is invariably higher than the interest rate quoted by the financier for 
the loan, but more accurately reflects the total cost of credit. It also provides a reliable benchmark for comparing competitive loan offers.

APR can be used to compare current financing offers to FEMP's data base of past Super ESPC awards by taking the index rate out of the calculation, which leaves premium and financing procurement price - the elements of total financing cost that can actually be controlled. If calculated APRs of competing offers appear to be inexplicable, or if the ESCO's best efforts resulted in only one SFO, the government will evaluate whether the APRs for the offers are in the program-wide competitive range.

Government evaluation of financing offers will provide straightforward, quantified data to inform the ESCO's selection of a financing offer, as well as assuring transparency in the financing transaction. FEMP routinely evaluates Super ESPC financing offers using a web-based calculator designed for this purpose. The calculator and the methodology are described in Appendix F. FEMP's technical team can turn around its evaluations in one day; if many financing offers are ready for evaluation at the same time, a week may be required.

The government reserves the right to contact prospective financiers to ask questions or seek clarification on issues related to the offer - but not to negotiate with the financier. Open communication between the government and financiers is intended to assure the transparency required to demonstrate and document due diligence in determining fair and reasonable pricing. Any communications between financiers and the government will include the ESCO, unless the ESCO waives participation.

\subsection{ESCO Recommendation of Financing Offer}

Using the government's APR evaluation as one criterion, the ESCO will select and recommend a financing offer. Selections based on APR require no further justification; selections based on other criteria, such as the financier's other terms and conditions, can be justified.

DOE offers no prescribed method to reach agreement on the selection of the finance offer. The development of an ESPC is a continual series of consensus agreements on all aspects of the project. In the interest of transparency and auditable due diligence, the ESCO shares information about the offers, recommends a selection, and gives the government the opportunity to agree. The ESCO selects the financing offer, with or without government agreement. However, during final negotiations the government considers all aspects of the ESCO's final proposal offer, and only issues an award if an acceptable project can be negotiated.

\subsection{Selection Memorandum and Certification}

After selecting a financing offer, the ESCO prepares a selection memorandum describing the competition, number of offers solicited and received, rationale for selecting the financier, and why the selection is the best value for the project. This process may be subject to audit by the government.

The ESCO shall certify to the government that the contents of the selection memorandum are true, correct, and in accord with best business practices. 


\subsection{Final Proposal Based on Selected Financing Offer}

The ESCO completes the final proposal using the conditions reflected in the selected financing offer. The process of finalizing the contract award remains the same. The government, financier, and ESCO work through the iterative financial analyses and adjustments that are commonly required to achieve positive cash flow during final negotiations.

Any differences in financing procurement price or premium over index between the ESCO's financing offer shown in Schedule DO-3 of the final proposal and the selected financing offer will be justified by the ESCO (documentation via e-mail or letter is acceptable).

The ESCO submits the IDS, SFO, selection memorandum, and certification with the price proposal in the final proposal, which becomes a part of the delivery order award. 


\section{APPENDIX A - \\ SUPER ESPC IDIQ MOdificATIONS RELATED to FinANCING (H.27)}

This appendix shows Section H.27 of the Super ESPC IDIQ as modified in

FY 2005. Section H.27 defines requirements related to financing.

\section{H.27 REQUIREMENTS FOR COMPETITIVE FINANCING ACQUISITION}

\section{H.27.1 Investor Deal Summary (IDS)}

The contractor shall submit the IDS (Attachment 9), along with the Contractor's Point of Contact, electronically in Microsoft Word format, to the Agency Contracting Officer, DOE CO and COR after completion of the DES.

\section{H.27.2 Competitive Financing Offers Based on Investor Deal Summary and Standard Financing Offers}

(a) The contractor shall solicit and select financing offers from the commercial market place through a competitive process. This process must incorporate the final IDS and require the financing offers to be in the form of the Standard Financing Offer (SFO) as set out in Attachment 10 to this Contract. Once this process is completed and a selection is made, the Contractor shall prepare a Selection Memorandum describing the selection process including the number of offers solicited and received, the rationale for selecting the financier, and the reasons why the selection is the best value for the project. This process may be subjected to audit by the government.

(b) The Contractor shall certify to the Government that the contents of the Selection Memorandum are true and correct and in accord with best business practice.

(c) The Contractor shall submit the IDS, SFO, Selection Memorandum and certification with its Price Proposal in the Final Proposal (H.24.2(d)). 
Appendix A

A - 2 


\title{
APPENDIX B - \\ TEXT FOR SUPER ESPC DO RFPS TO IMPLEMENT RECOMMENDATIONS OF FinANCING COST REDUCTION WoRKING GROUP
}

\author{
Finance-Related DO RFP Provisions
}

\section{H27.2 Three Competitive Financing Offers Based on Investor Deal Summary (IDS)}

The items listed herein supercede those specified in Section H.27.2 of the IDIQ contract.

(a) The Contractor shall solicit financing offers from at least three financing sources. The process must incorporate the final IDS and, at Contractor discretion, other project documentation that financiers request. Contractors that finance projects internally may count themselves as one of the three sources solicited. All resulting offers shall be submitted to the Contractor by the specified due date and contain, at least, the content defined in the Standard Financing Offer (SFO) as set out in Attachment 10 of the contract. Upon receipt the Contractor shall submit all resulting SFOs electronically in pdf format to the Federal agency and DOE CO and COR. When submitting the SFOs the Contractor shall provide a point of contact and shall request an agency evaluation period of not less than one week. Any communications with financiers desired by the Government (for clarifications, explanation of terms and conditions, etc.) shall be conducted jointly by Contractor and Government with the financier, unless the Contractor waives participation.

\section{H27.3 Government Evaluation of Financing Offer APRs}

The items listed herein are in addition to those specified in Section H.27 of the IDIQ contract.

Although the Contractor is free to estimate the annualized percentage rate (APR) of financing offers using methodologies of its own choice, the Government will determine the APRs of all SFOs using its own transparent methodology, and provide that information to the Contractor. If the Contractor's best efforts to solicit three financing offers resulted in only one SFO, the Government will evaluate whether the APR for that offer is in the program-wide competitive range. If multiple SFOs are received but their APRs appear to be inexplicable, the Government will evaluate whether the APRs are in the program-wide competitive range.

\section{H27.4 Contractor Recommendation of Financing Offers}

The items listed herein are in addition to those specified in Section H.27 of the IDIQ contract. 
The Contractor shall recommend and justify the financing offer selection, considering the Government's evaluation of APR and, where applicable, program-wide competitive range. The Government acknowledges that criteria beyond its own, such as the financier's other terms and conditions, have importance, and selections based on other criteria can be justified.

\section{H27.5 Final Proposal Based on Selected Financing Offer}

The items listed herein are in addition to those specified in Section H.27 of the IDIQ contract.

(a) The Contractor shall base its final proposal on the selected financing offer. The Government acknowledges that iterative financial analyses are common during the final proposal negotiations and award phase, in order to achieve positive cash flow after aspects of the project have changed (index portion of interest rate, $\mathrm{P} 4$ funds available, etc.), causing other aspects (the ECM bundle, performance-period term, etc.) to change as well. The Contractor and selected financier shall work through these iterations with the Government. The Contractor shall justify any differences between the Contractor financing offer proposed on Schedule DO-3 and the financing offer selected per this section.

(b) Once the selection process is complete and a selection is made, the Contractor shall prepare a Selection Memorandum describing the selection process including the number of offers solicited and received, the rationale for selecting the financier, and the reasons why the selection is best value for the project. This process maybe subject to audit by the government.

(c) The Contractor shall certify to the Government that the contents of the Selection Memorandum are true and correct and in accord with best business practice.

(d) The Contractor shall submit the IDS, SFO, Selection Memorandum and certification with its Price Proposal in the Final Proposal (H.24.2 (d)). 
Appendix C

\section{Appendix C - InVestor Deal Summary Template}

\section{Project:}

Date:

ESCO:

\begin{tabular}{|l|c|c|c|c|}
\hline \multicolumn{2}{|c|}{ 1. Project Investment } \\
\hline ECM description & $\begin{array}{c}\text { Implementation } \\
\text { expense (\$) }\end{array}$ & Markup (\%) & $\begin{array}{c}\text { Implementation } \\
\text { price (\$) }\end{array}$ & $\begin{array}{c}\text { Percentage of } \\
\text { implementation } \\
\text { price (\%) }\end{array}$ \\
\hline & & & & \\
\hline & & & & \\
\hline & & & & 100 \\
\hline Totals & & & & \\
\hline
\end{tabular}

\section{Key Project Dates}

\begin{tabular}{|c|c|}
\hline Key event & Date \\
\hline $\begin{array}{l}\text { a. Period over which to hold firm: } \\
\text { (i) offered premium over index interest rate } \\
\text { (ii) financing procurement price }\end{array}$ & \\
\hline b. Anticipated delivery order award & \\
\hline c. Anticipated financial closing & \\
\hline d. Index rate lock & \\
\hline e. Notice to proceed w/construction ${ }^{a}$ & \\
\hline f. Construction progress milestones ${ }^{a}$ & \\
\hline $25 \%$ completion & \\
\hline $50 \%$ completion & \\
\hline $75 \%$ completion & \\
\hline $100 \%$ completion & \\
\hline g. Government acceptance & \\
\hline 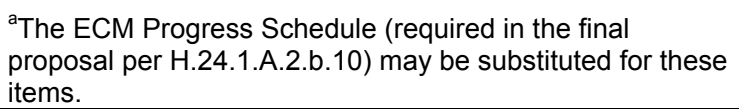 & \\
\hline
\end{tabular}


Appendix C

\section{Payment to Reduce Total Financed Amount}

\begin{tabular}{|l|l|l|}
\hline Type of payment & Amount (\$) & Anticipated date \\
\hline a. Pre-performance-period payment & & \\
\hline b. Utility rebate & & \\
\hline $\begin{array}{l}\text { c. Other ECM financial incentive (i.e. state } \\
\text { system benefit fund) }\end{array}$ & & \\
\hline
\end{tabular}

\section{ESCO's Portion of Financing Procurement Price}

\section{Summary Risk Analysis on Guaranteed Cost Savings (Payment Stream)}

\begin{tabular}{|l|c|c|c|c|c|c|}
\hline & \multicolumn{2}{|c|}{ Year 1 } & \multicolumn{2}{c|}{ Year 2 } & \multicolumn{2}{c|}{ Year 3 } \\
\hline Guaranteed annual cost savings & $\$$ & $\%$ & $\$$ & $\%$ & $\$$ & $\%$ \\
\hline${ }^{a}$ At risk & & & & & & \\
\hline${ }^{b}$ Low risk & & & & & & \\
\hline${ }^{c}$ No risk & & & & & & \\
\hline Total guaranteed savings & & & & & & \\
\hline
\end{tabular}

${ }^{a}$ Guaranteed savings "at risk" are subject to verification by ongoing measurements, such as M\&V Options B, C, and D.

${ }^{b}$ Low-risk guaranteed savings are subject to annual verification that ECM is in place and functioning, and savings from ECMs verified by M\&V Option $A$.

${ }^{c}$ No-risk guaranteed savings are from energy-related O\&M.

\section{Comparison of estimated and guaranteed cost savings}

Amount by which annual estimated cost savings exceed guaranteed cost savings (Values for Year 0, no escalation applied)

\begin{tabular}{|l|l|l|}
\hline \multicolumn{1}{|c|}{ Total project } & $\$$ & $\%$ \\
\hline Total estimated savings & & \\
\hline Total guaranteed savings & & \\
\hline Amount total estimated savings exceeds total guaranteed savings & & \\
\hline \multicolumn{1}{|c|}{ Savings in at-risk category } & & \\
\hline Estimated at-risk savings & & \\
\hline Guaranteed at-risk savings & & \\
\hline Amount estimated at-risk savings exceeds guaranteed at-risk savings & & \\
\hline
\end{tabular}


Appendix C

\section{Payments for Performance-Period Services}

\begin{tabular}{|l|l|l|c|}
\hline & Amount (\$) & $\begin{array}{c}\text { Anticipated start } \\
\text { date }\end{array}$ & $\begin{array}{c}\text { Frequency of payments } \\
\text { (monthly, quarterly, } \\
\text { annual) }\end{array}$ \\
\hline $\begin{array}{l}\text { Total performance-period services } \\
\text { payment }\end{array}$ & & & \\
\hline
\end{tabular}

\section{Savings Shortfall Required Before Exceeding Payment for ESCO Performance-Period Services}

\begin{tabular}{|l|l|l|l|}
\hline & Year 1 & Year 2 & Year 3 \\
\hline At-risk guaranteed savings (\$) & & & \\
\hline Performance-period services payment (\$) & & & \\
\hline $\begin{array}{l}\text { Percent shortfall in at-risk savings before } \\
\text { performance-period-services payment is exceeded }\end{array}$ & & & \\
\hline
\end{tabular}

\section{Events Required to Trigger Government Withholding of Payments and Likelihood of Occurrence}

[Text - Brief narrative describing post-acceptance events required to trigger government withholding of payments and likelihood of occurrence of those events.]

10. Applicable Financial Index (i.e. U.S. Treasury, Swap Rate, etc)

[ All financing offers are to be based on the financial index specified here.]

\section{Risk Assignment Summary: Refer to Completed Risk and Responsibility Matrix}

[Attach completed Risk and Responsibility Matrix.] 
Appendix C

C - 4 


\section{APPENDIX D - EXAMPLES OF RISK ANALYSIS OF SUPER ESPC ECMS}

\section{Examples of Risk Analysis of Super ESPC ECMs}

\begin{tabular}{|c|c|c|c|c|c|c|c|c|c|c|c|}
\hline \multirow[b]{2}{*}{$\begin{array}{l}\text { Pro- } \\
\text { ject }\end{array}$} & \multirow[b]{2}{*}{$\begin{array}{l}\text { ECM } \\
\text { No. }\end{array}$} & \multirow[b]{2}{*}{ ECM Description } & \multirow[b]{2}{*}{$\begin{array}{l}\text { Invest- } \\
\text { ment }\end{array}$} & \multicolumn{3}{|c|}{$\begin{array}{l}\text { Annual Cost Savings } \\
\text { Summary }\end{array}$} & \multirow[b]{2}{*}{$\begin{array}{l}\text { M\&V } \\
\text { Option }\end{array}$} & \multicolumn{3}{|c|}{ Savings by Risk Classification } & \multirow[b]{2}{*}{ Rationale for savings risk levels } \\
\hline & & & & $\begin{array}{l}\text { Annual } \\
\text { Energy } \\
\text { Cost } \\
\text { Savings }\end{array}$ & $\begin{array}{l}\text { Energy- } \\
\text { Related } \\
\text { Cost } \\
\text { Savings }\end{array}$ & $\begin{array}{l}\text { Total } \\
\text { Annual } \\
\text { Cost } \\
\text { Savings }\end{array}$ & & $\begin{array}{l}\text { No-Risk } \\
\text { Savings } \\
\text { (O\&M) }\end{array}$ & $\begin{array}{l}\text { Low- } \\
\text { Risk } \\
\text { Energy } \\
\text { Savings }\end{array}$ & $\begin{array}{l}\text { At-Risk } \\
\text { Energy } \\
\text { Savings }\end{array}$ & \\
\hline 16 & 1 & Lighting Upgrade & $\$ 272,773$ & $\$ 28,939$ & $\$ 3,402$ & $\$ 32,341$ & A & $\$ 3,402$ & $\$ 28,939$ & $\$ 0$ & $\begin{array}{c}\text { O\&M: Fully stipulated. Energy: Fully } \\
\text { stipulated after one-time post-installation } \\
\text { measurement. }\end{array}$ \\
\hline 16 & 2 & Water Conservation & $\$ 6,689$ & $\$ 567$ & $\$ 0$ & $\$ 567$ & A & $\$ 0$ & $\$ 567$ & $\$ 0$ & Energy (water savings): Fully stipulated. \\
\hline & & & & & \multirow{2}{*}{\multicolumn{3}{|c|}{$\begin{array}{l}\text { Project Totals: } \\
\text { Project Totals: }\end{array}$}} & $\$ 3,402$ & $\$ 29,506$ & $\$ 0$ & \\
\hline & & & & & & & & $10 \%$ & $90 \%$ & $0 \%$ & \\
\hline 18 & 1 & $\begin{array}{l}\text { Boiler retrofit/radiant } \\
\text { heating }\end{array}$ & $\$ 150,922$ & $\$ 6,449$ & $\$ 0$ & $\$ 6,449$ & $A, B$ & $\$ 0$ & $\$ 3,690$ & $\$ 2,700$ & $\begin{array}{c}\text { Energy: Low-Risk fully stipulated. At-Risk } \\
\text { have continuous energy usage } \\
\text { measurements. }\end{array}$ \\
\hline 18 & 4 & Lighting & $\$ 478,434$ & $\$ 49,763$ & $\$ 10,177$ & $\$ 59,940$ & A & $\$ 10,177$ & $\$ 49,763$ & $\$ 0$ & $\begin{array}{c}\text { O\&M: Fully stipulated. Energy: Fully } \\
\text { stipulated after one-time post-installation } \\
\text { measurement. }\end{array}$ \\
\hline 18 & 5 & Generator installation & $\$ 892,702$ & $\$ 122,348$ & $-\$ 5,000$ & $\$ 117,348$ & $\mathrm{~B}$ & $-\$ 5,000$ & $\$ 122,348$ & $\$ 0$ & $\begin{array}{l}\text { Low-Risk due to potential, although small, of } \\
\text { generator failure. }\end{array}$ \\
\hline 18 & 6 & Rate change & $\$ 5,000$ & $\$ 86,022$ & $\$ 0$ & $\$ 86,022$ & A & $\$ 86,022$ & $\$ 0$ & $\$ 0$ & $\begin{array}{c}\text { Only risk to savings occurs because ESCO } \\
\text { has O\&M responsibility for generator. }\end{array}$ \\
\hline & & & & & \multirow{2}{*}{\multicolumn{3}{|c|}{$\begin{array}{l}\text { Project Totals: } \\
\text { Project Totals: }\end{array}$}} & $\$ 91,199$ & $\$ 175,801$ & $\$ 2,700$ & \\
\hline & & & & & & & & $34 \%$ & $65 \%$ & $1 \%$ & \\
\hline 40 & 5 & GB IRS Lighting Retrofit & $\$ 156,514$ & $\$ 7,326$ & $\$ 2,173$ & $\$ 9,499$ & A & $\$ 2,173$ & $\$ 7,326$ & $\$ 0$ & $\begin{array}{l}\text { O\&M: fully stipulated. Energy: fully } \\
\text { stipulated after one-time post-installation } \\
\text { measurement. }\end{array}$ \\
\hline 40 & 5 & GB Courths Light Retrofit & $\$ 72,106$ & $\$ 4,789$ & $\$ 723$ & $\$ 5,512$ & A & $\$ 723$ & $\$ 4,789$ & $\$ 0$ & $\begin{array}{l}\text { O\&M: fully stipulated. Energy: fully } \\
\text { stipulated after one-time post-installation } \\
\text { measurement. }\end{array}$ \\
\hline 40 & 5 & RA Fed Bldg Light Retro & $\$ 254,536$ & $\$ 13,881$ & $\$ 4,101$ & $\$ 17,982$ & A & $\$ 4,101$ & $\$ 13,881$ & $\$ 0$ & $\begin{array}{c}\text { O\&M: fully stipulated. Energy: fully } \\
\text { stipulated after one-time post-installation } \\
\text { measurement. }\end{array}$ \\
\hline 40 & 3 & RA Fed Bldg EMS & $\$ 432,791$ & $\$ 21,966$ & $\$ 0$ & $\$ 21,966$ & D & $\$ 0$ & $\$ 21,966$ & $\$ 0$ & $\begin{array}{l}\text { Energy: Full stipulation based on calibrated } \\
\text { simulation. }\end{array}$ \\
\hline 40 & 1 & $\begin{array}{l}\text { RA Fed Bldg Chlr/Blr } \\
\text { Replacmt \& Rate Change }\end{array}$ & $\$ 904,131$ & $\$ 53,998$ & $\$ 0$ & $\$ 53,998$ & A & $\$ 0$ & $\$ 53,998$ & $\$ 0$ & $\begin{array}{l}\text { Energy: Fully stipulated after one-time post- } \\
\text { installation performance measurement. }\end{array}$ \\
\hline
\end{tabular}




\begin{tabular}{|c|c|c|c|c|c|c|c|c|c|c|c|}
\hline \multicolumn{12}{|c|}{ Appendix D } \\
\hline 40 & 5 & WI Light Retrofit & $\$ 77,698$ & $\$ 7,296$ & $\$ 943$ & $\$ 8,239$ & A & $\$ 943$ & $\$ 7,296$ & $\$ 0$ & $\begin{array}{l}\text { O\&M: fully stipulated. Energy: fully } \\
\text { stipulated after one-time post-installation } \\
\text { measurement. }\end{array}$ \\
\hline 40 & 8 & WI Motor Replacemt & $\$ 13,332$ & $\$ 323$ & $\$ 0$ & $\$ 323$ & A & $\$ 0$ & $\$ 323$ & $\$ 0$ & Energy: Fully stipulated. \\
\hline 40 & 2 & WI Chiller Replacemt & $\$ 306,923$ & $\$ 2,343$ & $\$ 0$ & $\$ 2,343$ & A & $\$ 0$ & $\$ 2,343$ & $\$ 0$ & $\begin{array}{l}\text { Energy: Fully stipulated after one-time post- } \\
\text { installation performance measurement. }\end{array}$ \\
\hline 40 & 5 & WN Crthse Light Retrofit & $\$ 279,771$ & $\$ 14,773$ & $\$ 3,820$ & $\$ 18,593$ & A & $\$ 3,820$ & $\$ 14,773$ & $\$ 0$ & $\begin{array}{l}\text { O\&M: fully stipulated. Energy: fully } \\
\text { stipulated after one-time post-installation } \\
\text { measurement. }\end{array}$ \\
\hline 40 & 8 & $\begin{array}{l}\text { WN Crthse VFD-S/R } \\
\text { Fans }\end{array}$ & $\$ 93,650$ & $\$ 7,869$ & $\$ 0$ & $\$ 7,869$ & A & $\$ 0$ & $\$ 7,869$ & $\$ 0$ & Energy: Fully stipulated. \\
\hline & & & & & \multirow{2}{*}{\multicolumn{3}{|c|}{$\begin{array}{l}\text { Project Totals: } \\
\text { Project Totals: }\end{array}$}} & $\$ 11,760$ & $\$ 134,564$ & $\$ 0$ & \\
\hline & & & & & & & & $8 \%$ & $92 \%$ & $0 \%$ & \\
\hline 45 & 5 & Lighting (Ab,Gr,Ja) & $\$ 282,081$ & $\$ 42,928$ & $\$ 3,964$ & $\$ 46,891$ & A & $\$ 3,964$ & $\$ 42,928$ & $\$ 0$ & $\begin{array}{l}\text { O\&M: fully stipulated. Energy: fully } \\
\text { stipulated after one-time post-installation } \\
\text { measurement. }\end{array}$ \\
\hline 45 & 8 & Airside VFDs & $\$ 258,307$ & $\$ 38,970$ & $\$ 0$ & $\$ 38,970$ & B & $\$ 0$ & $\$ 0$ & $\$ 38,970$ & $\begin{array}{l}\text { Energy: Usage measured continuously over } \\
\text { Year } 1 \text { to verify savings and stipulated } \\
\text { thereafter. }\end{array}$ \\
\hline 45 & 2 & Chillers & $\$ 704,680$ & $\$ 25,117$ & $\$ 7,000$ & $\$ 32,117$ & A & $\$ 7,000$ & $\$ 25,117$ & $\$ 0$ & $\begin{array}{l}\text { Energy: Spot measure system performance } \\
\text { in Year 1, stipulate thereafter. }\end{array}$ \\
\hline 45 & 5 & Lighting (Mo,Pa,Tu) & $\$ 609,345$ & $\$ 72,109$ & $\$ 9,956$ & $\$ 82,065$ & A & $\$ 9,956$ & $\$ 72,109$ & $\$ 0$ & $\begin{array}{c}\text { O\&M: fully stipulated. Energy: fully } \\
\text { stipulated after one-time post-installation } \\
\text { measurement. }\end{array}$ \\
\hline & & & & & \multirow{2}{*}{\multicolumn{3}{|c|}{$\begin{array}{l}\text { Project Totals: } \\
\text { Project Totals: }\end{array}$}} & $\$ 10,964$ & $\$ 68,045$ & $\$ 38,970$ & \\
\hline & & & & & & & & $9 \%$ & $58 \%$ & $33 \%$ & \\
\hline 52 & 2 & $\begin{array}{l}\text { Chiller upgrade (convert } \\
\text { to variable speed) }\end{array}$ & $\$ 1,183,502$ & $\$ 113,302$ & $\$ 0$ & $\$ 113,302$ & B & $\$ 0$ & $\$ 0$ & $\$ 113,302$ & $\begin{array}{l}\text { Energy: Spot measurements of performance } \\
\text { for lead (annual) and secondary (one-time) } \\
\text { chillers. Continuous measurement of chiller } \\
\text { run times. }\end{array}$ \\
\hline 52 & 3 & $\begin{array}{l}\text { Controls upgrades }(9 \\
\text { bldgs) }\end{array}$ & $\$ 484,714$ & $\$ 76,899$ & $\$ 0$ & $\$ 76,899$ & $\mathrm{~B}$ & $\$ 0$ & $\$ 0$ & $\$ 76,899$ & $\begin{array}{l}\text { Energy: Continuous measurement of run- } \\
\text { times. }\end{array}$ \\
\hline 52 & 5 & $\begin{array}{l}\text { Lighting upgrades ( } 8 \\
\text { bldgs) }\end{array}$ & $\$ 980,574$ & $\$ 125,598$ & $\$ 0$ & $\$ 125,598$ & A & $\$ 0$ & $\$ 125,598$ & $\$ 0$ & $\begin{array}{l}\text { Energy: Fully stipulated after one-time post- } \\
\text { installation performance measurement. }\end{array}$ \\
\hline 52 & 11 & Daylighting (23-27) & $\$ 48,644$ & $\$ 3,148$ & $\$ 0$ & $\$ 3,148$ & A & $\$ 0$ & $\$ 3,148$ & $\$ 0$ & $\begin{array}{l}\text { Energy: Fully stipulated after one-time post- } \\
\text { installation performance measurement. }\end{array}$ \\
\hline 52 & 11 & Daylighting (20-6) & $\$ 52,043$ & $\$ 4,663$ & $\$ 0$ & $\$ 4,663$ & A & $\$ 4,663$ & $\$ 0$ & $\$ 0$ & No-Risk savings are energy: Full stipulation. \\
\hline & & & & & \multirow{2}{*}{\multicolumn{3}{|c|}{$\begin{array}{l}\text { Project Totals: } \\
\text { Project Totals: }\end{array}$}} & $\$ 4,663$ & $\$ 128,746$ & $\$ 190,201$ & \\
\hline & & & & & & & & $1 \%$ & $40 \%$ & $59 \%$ & \\
\hline & & & & & \multirow{2}{*}{\multicolumn{3}{|c|}{$\begin{array}{l}\text { Across Project Totals: } \\
\text { Across Project Totals: }\end{array}$}} & $\$ 121,988$ & $\$ 536,662$ & $\$ 231,871$ & \\
\hline & & & & & & & & $14 \%$ & $60 \%$ & $26 \%$ & \\
\hline
\end{tabular}




\section{Appendix $\mathrm{E}$}

\section{APPENDIX E - \\ StANDARD FinANCING OfFER TEMPLATE}

Financier Note: SFO is to be submitted on company letterhead.

Project:

Date:

ESCO:

Narrative description of finance package:

Financier Note: This section is intended to communicate full understanding of the finance offer, addressing issues such as:

- $\quad$ Third party or internal financing of capitalized construction-period interest costs

- Establishment of escrow or trust accounts for construction draws, performance-period administration, or other purposes

- $\quad$ Timing of project financing closing and date certain for initiation of repayments (if applicable)

- $\quad$ Timing of Government payments (monthly, quarterly, annually in advance, monthly in arrears, etc.)

Implementation Price (IP) (value from IDS):

Itemized Financing Procurement Price (FPP):

Financier Note: Itemize all up-front charges that flow to Financing Procurement Price (FPP) in Schedule DO-3 of the Contractor's final proposal, such as:

- $\quad$ All fees, professional services, etc. (itemize individually)

- $\quad$ Capitalized construction-period interest (state all interest rate and other assumptions not specified in IDS) 


\section{Appendix E}

- $\quad H e d g e$ costs (only applicable if IDS indicates Government desires the index portion of total project interest rate to be held firm along with premium over index and FPP)

- $\quad$ Plug figure for Contractor's portion of FPP (price to arrange financing, pass-through of payment and performance bond cost, etc.; value from IDS)

Pre-performance-period payments (P4s, value from IDS):

Total Amount Financed (IP + FPP - P4):

Financial Summary:

Date to which all aspects of the offer are held firm (from IDS):

Premium over index interest rate (annual):

Financier Note: If Government desires the index to be held firm, then specify project interest rate (annual).

Financier portion of FPP :

Financier Note: Total FPP, less plug figure for Contractor's portion

Performance period (i.e., financing repayment) term (months):

Financier Note:

1. Schedule of Government debt service payments, electronically in Excel format, including all supporting calculations shall be provided with SFO.

2. Backup for the value of capitalized construction period interest, electronically in Excel format, including all supporting calculations, shall be provided with SFO.

All financing offers shall be based upon the applicable financial index specified in the IDS. The maturity of the index rate shall be equal to the performance period term (i.e. 17-year performance period $=17$-year index). If the performance period is not exactly equal to the maturity of a specific index, then it is recommended that a smoothed cubic spline fit be used to approximate the rate curve. This method allows the interpolation of interest rates for given maturities even when no paper was sold at those maturities. For a discussion of econometric techniques for fitting the term structure of interest rates, including bibliographic information, see, for example, Mark Fisher, Douglas Nychka, and David Zervos, "Fitting the Term Structure of Interest Rates with Smoothing Splines," Finance and Economics Discussion Series 95-1 (Board of Governors of the Federal Reserve System, January 1995). 


\section{APPENDIX F - \\ CALCULATING INDEX RATE USing SPLINE INTERPolation AND APR CALCULATOR}

\section{Calculation of Index Interest Rate Using Spline Interpolation}

Paragraph H.27.2 (c) of the IDIQ modifications states that all financing offers shall be based on the financial index specified in the IDS, and that the maturity of the index rate shall be equal to the performance period. For example, for an ESPC with a 17-year performance period, the index used should reflect a maturity of 17 years.

At present, Treasury Yield Curve Rates, commonly referred to as Constant Maturity Treasury rates (CMTs), are the most widely used financial index. On the website http://www.ustreas.gov/offices/domestic-finance/debt-management/interest-rate/yield.html, the U.S. Treasury publishes the yield rates of CMTs with maturities of 1, 3, and 6 months and 1, 2, 3, $5,7,10$, and 20 years. The Treasury ceased publication of the 30 -year constant maturity series in 2002, but publishes a daily extrapolation factor which, when added to the yield of a 20-year CMT, provides an estimate for a theoretical 30-year rate. The extrapolation factor is available at http://www.ustreas.gov/offices/domestic-finance/debt-management/interestrate/ltcompositeindex.html.

The theoretical yield of a 30-year CMT provides an additional point for the yield curve. However, since the terms of most ESPCs do not correspond to any of the published CMT maturities, interpolation is required. On the advice of Treasury, FEMP requires that the interpolation be performed with cubic splines (Adams, 2004). Splines are piecewise, third-order polynomials that connect a set of points, and are continuous in the first and second derivatives (Bartels et al., 1998).

Consider a cubic spline that fits $n$ points $\left(x_{1}, y_{1}\right),\left(x_{2}, y_{2}\right), \ldots,\left(x_{n}, y_{n}\right)$. The spline will consist of $n-1$ segments ( 1 through $n-1)$, where the $\mathrm{j}^{\text {th }}$ segment connects points $\left(x_{j}, y_{j}\right)$ and $\left(x_{j+1}, y_{j+1}\right)$. Following the derivation presented by Press et al. (1992), the equation of the spline curve connecting these two points is:

$$
y=A y_{j}+B y_{j+1}+C y_{j}^{\prime \prime}+D y_{j+1}^{\prime \prime}
$$

Here $y_{j}^{\prime \prime}$ and $y_{j+1}^{\prime \prime}$ are the second derivatives of the spline at the points $\left(x_{j}, y_{j}\right)$ and $\left(x_{j+1}, y_{j+1}\right)$, respectively, and $\mathrm{A}, \mathrm{B}, \mathrm{C}$, and $\mathrm{D}$ are given by the following:

$$
\begin{gathered}
A=\frac{x_{j+1}-x}{x_{j+1}-x_{j}} \\
B=1-A
\end{gathered}
$$




$$
\begin{aligned}
& C=\frac{1}{6}\left(A^{3}-A\right)\left(x_{j+1}-x_{j}\right)^{2} \\
& D=\frac{1}{6}\left(B^{3}-B\right)\left(x_{j+1}-x_{j}\right)^{2}
\end{aligned}
$$

The second derivatives are given by:

$$
\frac{x_{j}-x_{j-1}}{6} y_{j-1}^{\prime \prime}+\frac{x_{j+1}-x_{j-1}}{3} y_{j}^{\prime \prime}+\frac{x_{j+1}-x_{j}}{6} y_{j+1}^{\prime \prime}=\frac{y_{j+1}-y_{j}}{x_{j+1}-x_{j}}-\frac{y_{j}-y_{j-1}}{x_{j}-x_{j-1}} \text {. }
$$

Equation (6) contains $n$ unknowns, $y_{1}^{\prime \prime}$ through $y_{n}^{\prime \prime}$. Since there are $n-2$ equations (one each for $\mathrm{j}=2$ through $n-1$ ), two additional conditions are required. The most common assumption is to set $y_{1}^{\prime \prime}$ and $y_{n}^{\prime \prime}$ equal to zero, resulting in a so-called natural spline.

To perform the interpolation, a natural spline fit is performed using daily CMT yields with maturities of $1,2,3,5,7,10$, and 20 years, and the theoretical yield of a 30-year CMT. Maturities of less than one year are not used because their yields do not seem to be continuous with the yield of longer-term CMTs. In any case, the average Super ESPC project term is 17 years, and no project has had a term of less than three years.

FEMP has developed a web-based calculator to perform the interpolation based on the most recent Treasury yield curve rates. Since this calculator automatically obtains current yield curve data from the Treasury's web pages, the only required input is the project term. Once this is entered, the calculator determines the index rate corresponding to that term.

A web-based calculator for spline interpolation of interest rates will be available at http://www.eere.energy.gov/femp/financing/superespcs_contracttools.cfm.

\section{Calculation of Annual Percentage Rate}

In an ESPC, the financed amount (FA) is equal to the implementation price of the ECMs (IP) plus the financing procurement price (FP) minus any pre-performance-period payment (P4). In other words, $\mathrm{FA}=\mathrm{IP}+\mathrm{FP}-\mathrm{P} 4$. This is financed at the project interest rate $(r)$ for a period of time $n$ equal to the project term. Annual percentage rate (APR) is defined as the rate of interest that would result in the same sum of payments over the project term, if the finance procurement price were not included in the financed amount, but instead was paid as interest.

Annual Percentage Rate (APR) - A percentage calculation that reflects the total cost of a loan (interest plus fees) on an annual basis. The APR calculated by the government on financing offers for Super ESPCs includes the index interest rate, the ESCO's added premium, and the up-front finance procurement price. The APR is invariably higher than the interest rate quoted by the financier for the loan, but more accurately reflects the total cost of credit. It also provides a benchmark for comparing competitive loan offers. 
In mathematical terms, the payment $p$ on a loan in the amount of IP $+\mathrm{FP}-\mathrm{P} 4$, with an interest rate of $r$, for $n$ periods is:

$$
p=(I P+F P-P 4) \frac{r(1+r)^{n}}{(1+r)^{n}-1}
$$

If the payment is to be the same on a loan in the amount of IP - P4 for the same term, then the interest rate $a$ - the annual percentage rate — must satisfy:

$$
(I P+F P-P 4) \frac{r(1+r)^{n}}{(1+r)^{n}-1}=(I P-P 4) \frac{a(1+a)^{n}}{(1+a)^{n}-1}
$$

Since there is no analytical way to solve for $a$ in equation (8), it must be solved through iteration. FEMP has developed a web-based calculator that determines APR $a$ given the implementation price, financing procurement price, project interest rate, project term, and the amount of any preperformance-period payment. The calculator is available at http://www.ornl.gov/sci/femp/.

A web-based APR calculator will be available at

http://www.eere.energy.gov/femp/financing/superespcs_contracttools.cfm.

\section{Appendix F References}

Adams, F. A., Deputy Director, Office of Debt Management, Department of the Treasury. Personal communication to John Shonder, October 2004.

Bartels, R. H.; Beatty, J. C.; and Barsky, B. A. "Hermite and Cubic Spline Interpolation." Ch. 3 in An Introduction to Splines for Use in Computer Graphics and Geometric Modelling. San Francisco, CA: Morgan Kaufmann, pp. 9-17, 1998.

Press, W. H.; Flannery, B. P.; Teukolsky, S. A.; and Vetterling, W. T. "Cubic Spline Interpolation." $\$ 3.3$ in Numerical Recipes in FORTRAN: The Art of Scientific Computing, 2nd ed. Cambridge, England: Cambridge University Press, pp. 107-110, 1992. 